\title{
КОЛЕГИ, ОПОНЕНТИ: ДЕКІЛЬКА ЗАУВАГ ПРО ОСОБИСТІ ТА ТВОРЧІ КОНТАКТИ БОРИСА ГРІНЧЕНКА І МИХАЙЛА КОЦЮБИНСЬКОГО
}

\author{
ДМИТРО ЄСИПЕНКО \\ Інститут літератури ім. Т. Г. Шевченка НАН України, Київ - Україна \\ WSPÓŁPRACOWNICY, PRZECIWNICY: \\ KILKA UWAG NA TEMAT OSOBISTEJ I ARTYSTYCZNEJ WIĘZI \\ BORYSA HRINCZENKI I MYCHAJŁA KOCIUBYNSKIEGO \\ DMYTRO JESYPENKO \\ Instytut Literatury im. Tarasa Szewczenki NAN Ukrainy w Kijowie, \\ Kijów - Ukraina
}

STRESZCZENIE. W artykule została przedstawiona historia znajomości, korespondencji i współpracy ukraińskich pisarzy - Borysa Hrinczenki oraz Mychajła Kociubynskiego. Autor skupia się na ich pobycie w Czernihowie, warunkach pracy w ziemstwie gubernialnym, udziale w działalności lokalnej wspólnoty ukraińskiej. Opisane zostały także podobieństwa i różnice charakterów oraz światopoglądów obu literatów.

\section{COLLEAGUES, OPPONENTS: A FEW REMARKS ABOUT PRIVATE AND ARTISTIC CONTACTS BETWEEN BORYS HRINCHENKO AND MYKHAILO KOTSIUBYNSKYI}

\section{DMYTRO YESYPENKO}

T. H. Shevchenko Institute of Literature, National Academy of Sciences of Ukraine,

Kyiv - Ukraine

\begin{abstract}
The article deals with the history of the writers dating, correspondence and cooperation. It widely highlights their simultaneous sojourn in Chernihiv, working conditions in the Gubernatorial council, participation in the activity of the local Ukrainian community. It also defines similarities and differences between the authors characters and ideology.
\end{abstract}

\footnotetext{
3
} іставлення творчих постатей Михайла Коцюбинського та Бориса Грінченка досі не було предметом розгляду окремої студії. Безсумнівно, значний пізнавальний потенціал має інтерпретаційне порівняння їхніх художніх текстів: пошук можливих перегуків, з’ясування міри вияву традиційного та модерного в манері письма тощо. Не менш перспективним видається також вивчення контроверсійної історії критичної рецепції творчості двох класиків, виявлення періодів уведення та вилучення з українського літературного канону. Утім, аби уникнути ризику широкого, але поверхового окреслення визначеного питання, в цій статті звернемо увагу передовсім на його суто біографічний аспект: особисті взаємини та співпрацю двох літераторів. 
Письменники слідкували за творчими успіхами один одного ще до особистого знайомства. Так, 1892 р. в листі до В. Лукича М. Коцюбинський прохав надіслати йому черговий випуск газети ,Зоря”, аби мати можливість дочитати повість Б. Грінченка На розпутmi. Уперше літератори могли побачитися 1893 р. під час з’їзду „Братства тарасівців” - таємної молодіжної організації, що ставила за мету національно-культурне відродження та державну самостійність України. Серед трьох десятків делегатів київського з’їзду місцеві осередки, ймовірно, представляли й Б. Грінченко (один із засновників організації) та М. Коцюбинський (iї активний учасник) ${ }^{2}$.

Досить жвавий епістолярний діалог письменників розпочався 1894 р. Ініціатором виступив Б. Грінченко, попрохавши колегу надіслати свої твори для публікації в чернігівській серії народно-просвітних книжок³. М. Коцюбинському цей задум був дуже близький, тож він охоче дав дозвіл на видання своїх оповідань для дітей ${ }^{4}$ (1895 р. з'явилися друком П'ятизлотник, Харитя, Ялинка та Маленький грішник)5. Однак уже невдовзі виявилися деякі розбіжності в поглядах авторів на призначення їхніх творів. У листі Б. Грінченкові М. Коцюбинський так пояснював відмову надіслати свої нові оповідання для чергового видання: „Ви видаєте книжки переважно для селян, а мої оповідання не придатні для сільської бібліотеки"б.

Особисте знайомство письменників сталося наприкінці 1894 р., коли під час короткого візиту до Чернігова М. Коцюбинський скористався запрошенням відвідати помешкання Бориса та Марії Грінченків. Цікаво, що тоді ж відбулося його знайомство $з$ майбутньою дружиною, В. Дейшою7 1895 р. М. Коцюбинський взяв участь у комплектуванні знакового для української фольклористики видання - Этнографические материаль, собраннье в Черниговской и соседних с ней губерниях. Надіслані ним 11 пісень у власному записі, а також 98 - занотованих Андрієм Дуляком - упорядник, Б. Грінченко, вмістив у третьому томі збірника ${ }^{8}$.

1897 р. М. Коцюбинський заохочував Б. Грінченка до співпраці з житомирською газетою „Волынь”, у якій він спершу завідував конторою, а згодом редагував рубрики „Хроника” і „Свет и тени русской жизни”. Цей намір виявився результативним - грінченкову замітку під титулом Из заметок о сельских чтениях було надруковано в газеті за 30-31 січня 1898 р. за підписом „Ив. П.”. У листі до дружини М. Коцюбинський свідчив про цей матеріал: „Стаття нічого, цікава. Я дуже радий, що мені удалося відстояти іiі, бо редактор вчора був проти неї і не хотів навіть друкувати..." . Відзначимо, що огляди Б. Грінченка Из новостей украинской литературы з'являлися у „Волыни” й згодом, коли М. Коцюбинський залишив Житомир ${ }^{10}$.

${ }^{1}$ М. Ко цю би н с ь ки й, Твори в 7 m., упор. та прим. Н. О. Іш и но ̈, Київ 1974, т. 5, с. 32.

${ }^{2}$ Ю.М.Коцюбинський, М. Коиюбинський та ,Братство тарасівиів”, [в:] „Наукові записки" Чернігів 1996, вип. 1, с. 79-81.

3 Листи до Михайла Коџюбинського, упор. та комент. В. М а 3 н о г о, Ніжин 2002, т. 3, с. 54-55.

${ }^{4}$ М. Коцюбин с ький , Твори..., т. 5, с. 44-45.

${ }^{5}$ Г. В . С ам ойл е н ко, Громадсько-культурне та літературне життя в Чернігові в кінці XIX-на початку XX cm., [в:] ,Література та культура Полісся” 1998, вип. 10, с. 11.

${ }^{6}$ М. Коцюби н сь ки й, Твори..., т. 5, с. 56.

7 Й. Я. Ку п ' я н с ь к и й, Літопис життя і творчості Михайла Коиюбинського, Київ 1965, c. 54 .

${ }^{8}$ Б. Грин ченко, Этнографические материаль, собранные в Черниговской и соседних с ней губерниях, Чернигов 1899, т. 3, с. VIII; М. Коцюбин ськи й, Твори..., упор. та прим. С. П. Шмаглій, М. С. Грицюти та О. І. Гонча ра, т. 4, с. 379.

${ }^{9}$ М. К К ц ю б и н с ь К и й, Я так поріднився з тобою.... Листи до дружсини, Київ 2007, с. 137.

${ }^{10}$ Б. Гр и н че н ко , Из новостей украинской литературы, [в:] „Волынь”, 1902, № 4-42. 
Спільним місцем роботи для обох письменників стало Чернігівське губернське земство. Б. Грінченко працював тут з 1894 р.: спершу на посаді діловода, згодом - секретаря. Найпевніше, що ініціатива запрошення М. Коцюбинського до земства належала саме йому, а також багаторічному лідеру чернігівських українців Іллі Шрагу ${ }^{11}$. Ще 1896 р. Б. Грінченко цікавився розміром оплати, яка би влаштовувала колегу; обіцяв пошукати в Чернігові варіанти, відповідні його запитам (принаймні 800-900 рублів щорічно) ${ }^{12}$.

М. Коцюбинському не відразу вдалося дістати посаду в земстві. Як зауважують дослідники життя й творчості письменника, 1897 р. на перешкоді цьому стали непорозуміння 3 місцевою владою ${ }^{13}$. Дійсно, чернігівський губернатор $€$. Андрієвський нерідко настирливо втручався в земські справи. Одначе на перешкоді призначенню М. Коцюбинського стали не його старання, а характеристика, надана департаментом поліції з приводу можливості обійняти посаду завідувача книжковим складом земства. У ній зазначалося, що літератор „принадлежит к крайним украинофилам, а в качестве такового может заняться распостранением среди населения Черниговской губернии тенденциозных малорусских изданий”. Позитивний відгук від Є. Андрієвського дозволяв письменникові ще восени 1897 р. отримати одну з посад у земстві (окрім завідування книжковим складом) ${ }^{14}$, однак цього не сталося. Окрім тривалого зволікання, слід відзначити й цілковиту непоінформованість головного фігуранта справи. Ще на початку 1898 р. М. Коцюбинський сумнівався в можливості своєї служби в Чернігові. У лютому цього ж року він заявляв про своє прагнення обійняти посаду „делопроизводителя оценочного стола", що звільнилася після призначення Б. Грінченка секретарем управи. М. Коцюбинський прохав колегу „замовити прихильне слово" перед тодішнім головою земства Ф. Уманцем. Прикметно, що він не поспішав прибути до Чернігова особисто, побоюючись утратити місце служби в Криму ${ }^{15}$. Саме 3 грінченкових листів він дізнавався про перипетії справи та призначення на бажану посаду в земстві ${ }^{16} .1900$ р. М. Коцюбинський став працівником земського статистичного бюро; до кола його обов'язків належало укладання та редагування щорічника „Сельськохозяйственные обзоры по Черниговской губернии”.

Разом із Б. Грінченком та М. Коцюбинським, у земстві працювали також В. Самійленко та М. Чернявський. Варто згадати й приклад особливої “корпоративної солідарності” українських літераторів. У листопаді 1899 р. вийшло розпорядження, що зобов'язувало канцелярських службовців залишатися на роботі, поки не підуть члени управи. 3 цього приводу В. Самійленко, М. Коцюбинський та інші виступили із заявою; до них приєднався і Б. Грінченко 3 такою мотивацією: „По обязанностям своей службы я должен быть на службе до ухода самой Управы, почему упоминаемое здесь распоряжение ко мне не могло относиться, но принципиально я присоединяюсь ко взгляду моих сослуживцев на исполнение их обязанностей" ${ }^{17}$.

${ }^{11}$ А. Верзилів, М. Грінченко, 3 життя чернігівської Громади 1880-90 рр., [в:] „Чернігів і північне лівобережжя”, Київ 1928, с. 472-473.

${ }^{12}$ Листи до Михайла Коиюбинського..., т. 3, с. 70.

${ }^{13}$ А. Лебі дь, Пропащчі роки (До біографії М. М. Коџюбинського), [в:] „Україна” 1927, Кн. 3 , с. 90.

${ }^{14}$ Й. Я. Куп ’ ян с ь к ий, Літопис життя..., с. 87, 90.

${ }^{15}$ М. Ко цюб и н ський, Твори..., т. 5, с. 127-129.

${ }^{16}$ М. Коц юб и н сь к и й, Я так поріднився з тобою..., с. $149,153$.

${ }^{17}$ В. Самійленко, М. Коцюбинський та ін., Заява до Чернігівської губернської управи службовців управи, [в:] Інститут рукопису Національної бібліотеки України ім. В. І. Вернадського, ф. I, спр. 31749, арк. 1. 
Слід звернути увагу й на іншу важливу сторінку культурно-просвітньої активності Б. Грінченка та М. Коцюбинського в Чернігові — участь у діяльності місцевої української громади, нелегального об'єднання національно свідомої інтелігенції. У час служби письменників у земстві до ії складу входило близько двадцяти осіб. Герої цієї статті, а також Ілля Шраг, Аркадій Верзилів та Віра Коцюбинська репрезентували чернігівців на річних з'їдах представників громад різних міст етнічної України ${ }^{18}$. Цікаву згадку про одне із таких зібрань залишив С. Єфремов: „Коцюбинський дуже близько стояв до перводжерел українського громадського життя, бувши членом нелегальної громади в Чернігові та приїздячи од неї частенько делегатом на з'їзди (так само нелегальні) Всеукраїнської організації, що відбувались звичайно в Києві двічі або й тричі на рік. На початку 900-х років він бував звичайним учасником цих з'їдів. Пам'ятаю, що на одному з їх, року, либонь, 1901-го, відбувся в квартирі Антоновича між ним та другим визначним тоді ще чернігівцем, Борисом Грінченком, надзвичайно цікавий турнір, в якому обидва промовці розгорнули — кожен з свого погляду — цілу програму методів громадської праці на українському грунті. Вражіння цей турнір викликав серед присутніх величезне, і Є. Х. Чикаленко сформулював його по засіданні словами: „Ну, маємо вже зовсім готових послів до майбутнього українського парламенту", розуміючи в цьому, що такі промовці зуміють кожну справу на повен зріст поставити. 3 цього бачимо, що промовляти Коцюбинський міг справді гарно, із захватом, коли зважувався ставати поруч суворої, непохитної логіки Грінченка, безперечно визначного промовця" ${ }^{\text {. }}$.

Серед широкого кола просвітніх заходів, реалізованих членами чернігівської громади, варто назвати організацію гуртків самоосвіти, на яких читали лекції з української історії (Б. Грінченко і Г. Коваленко) та літератури (М. Коцюбинський і М. Чернявський). Грінченки та Коцюбинські в різний час були членами правління Чернігівської громадської бібліотеки, можливості якої громадівці використовували для поширення освітніх та національних ідей.

Б. Грінченко бував на традиційних літературних „понеділках” (що змінилися „суботами”) у садибі М. Коцюбинського на вулиці Сіверянській. Під виглядом приватних вечірок на цих зустрічах відбувалося читання та обговорення літературних творів, а також актуальних питань суспільно-громадського життя. Прикметно, що Грінченкам було заборонено влаштовувати зібрання у своєму помешканні ${ }^{20}$.

Спільна активна участь письменників у нелегальних заходах відображена на сторінках жандармських донесень про діяльність М. Коцюбинського: „Крайне сомнительный в политическом отношении, вожак украинофильской партии, в близких отношениях с Гринченко и другими земскими деятелями”; „личность безусловно вредная по своим противоправительственным взглядам; весьма развитой и умный человек, большой друг Гринченко”. Формулювання на зразок „друг и единомышленник Гринченко” перемандровували із донесення в донесення протягом 1899-1902 pp. ${ }^{21}$.

Важливими заходами письменників літературного характеру стала підготовка альманахів. 1898 р. письменники-чернігівці (В. Самійленко, Б. Грінченко та Г. Коваленко), разом із М. Коцюбинським, що саме приїхав до міста, задумали випустити збірник художніх текстів колег-сучасників під титулом „Хвиля за хвилею”. Намір було реалізовано, і 1900 р. він вийшов друком. Наступного року

\footnotetext{
${ }^{18}$ Г. В. Самойленко, Громадсько-культурне..., с. 23.

${ }^{19}$ C. С фр ем о в, Вибране: статті, наукові розвідки, монографї, Київ 2002, с. 249.

${ }^{20}$ Г. В . С ам о йл е н ко, Громадсько-культурне..., с. 45.

${ }^{21}$ Й. Я. Куп'ян с ь ки й, Літопис життя..., с. 128, 134, 153.
} 
Б. Грінченко, М. Коцюбинський та М. Чернявський звернулися до українських письменників з відозвою про укладання нового альманаху — „Дубове листя”. Цей збірник на пошану П. Куліша з'явився 1903 р. в Києві з передмовою Б. Грінченка. Цікаві мемуарні свідчення про спільну роботу над підготовкою видання залишив М. Чернявський. Саме під час ії виконання він особливо відчув відмінності „як взагалі щодо розуміння й оцінки творів і письменників, так, головним чином, щодо їх мови. Коцюбинського принаджувала в творах, так мовити, їх екзотичність, часом штучність, взагалі те, що здавалось йому новим і орігінальним. Грінченкові більше подобались твори вільні від штучности, він любив писання реальне, правдиве й доступне широким масам. Щодо мови, Коцюбинський був прихильником мови західноукраїнської й почасти галицької, а Грінченко навпаки"22. Розбіжності в поглядах письменників на роль та призначення художніх текстів увиявнилися в несхвальному відгуку Б. Грінченка про характер альманаху “3 потоку життя”, замисленого М. Чернявським та М. Коцюбинським як збірка текстів насамперед про життя сучасної інтелігенції: „Від вашого заклику пахне устрицями" 23 . Попри тісну співпрацю в різних сферах українського культурно-громадського життя, особливого зближення між літераторами все ж не відбулося. Промовистий факт - в епістолярії М. Коцюбинський не раз з іронією іменував Б. Грінченка "Генералом" (приміром, у листах до дружини 1896-1898 pр. зустрічається переважно саме така форма $\left.{ }^{24}\right)$. Це прізвисько він отримав за гордий та непоступливий характер, вимогливість до себе й оточуючих, безапеляційний тон спілкування. Титул “єнерала” давав Б. Грінченкові й адресант М. Коцюбинського О. Кониський ${ }^{25}$. Для порівняння - А. Кримський, Т. Зіньківський, М. Чернявський, С. Сфремов, з якими у Б. Грінченка склалися особливо довірливі, дружні стосунки, - так його не називали.

Свідомий недоліків характеру колеги по перу й по службі, М. Коцюбинський відзначав і позитиви його діяльної вдачі. Він був переконаний у моральних чеснотах Б. Грінченка, а тому рішуче відкидав чутки, що їх поширювали злозичливці останнього: „Так мішати з болотом людину, до того людину чесну (я певен у цьому), не годиться порядним людям. Коли у Грінченка $є$ які вади, то ще 3 цього не випливає, щоб на підставі спліток так ганьбити людину і одмовляти йому навіть в чесності. Мені це дуже прикро, і мої симпатії схиляються на бік Грінченка"26. Реагуючи на прохання Я. Жарка схарактеризувати Б. Грінченка, М. Коцюбинський відзначав передовсім його велику працьовитість та значний талант ${ }^{27}$.

Міркування М. Коцюбинського про своє та грінченкове творче обдарування, його генетичну вмотивованість, зафіксував все той самий М. Чернявський. У дружній розмові письменники обговорювали етнічну приналежність один одного й з'ясували, що „батьки у нас були чистої української крові, а матері - чужої. У нас з Грінченком - великоросійської, у Коцюбинського - кавказької. Здається, осетинської <..>.

- Виходе, що всі ми троє — гібріди, — сказав Коцюбинський. Що ж, це непогано. В ботаніці відомо, що сполучення двох близьких видів рослин утворює нову посилену ріжновидність. Що до квіток, то два види, бувши сполучені, дають нові кращі квітки. Може, цим пояснюються й наші вдачі” 28 .

\footnotetext{
${ }^{22}$ М. Ч ер н я в сь к и й, Кедр Ливана: Спогади про Б. Грінченка, Херсон 1920, с. 23.

${ }^{23}$ Г. В . С амой ленко, Громадсько-культурне..., с. 66.

${ }^{24}$ М. . Ко ц ю б и н с ь к й , Я так поріднився з тобою..., с. 28-156.

25 Листи до Михайла Коияюбинського, Ніжин 2002, т. 3, с. 96.

26 Там само, с. 134.

${ }^{27}$ М. Ко цюб и н с ь ки й, Твори..., т. 5, с. 223.

${ }^{28}$ М. Ч ер н я в с ь к и й, Кедр Ливана..., с. 28.
} 
Значний дослідницький інтерес має з'ясування ролі Італії як географічного простору, так і культурного (мовного, історичного) феномену в житті та творчості Б. Грінченка та М. Коцюбинського. Обидва письменники побували в цій країні (як туристи й на лікуванні), залишивши яскраві враження в епістолярії та художніх текстах. До вивчення ,італійських”, зокрема „капрійських", епізодів біографії М. Коцюбинського дослідники зверталися значно частіше й результативніше, оприлюднивши спеціальні студії з цього питання ${ }^{29}$, тоді як перебування Б. Грінченка в Оспедалетті відображено лише в неопублікованих листах та спогадах його близьких ${ }^{30}$. Безперечно, кожен із біографічних сюжетів, згаданих вище, вартий докладнішого розгляду в межах окремих історикота теоретико-літературних досліджень. Побіжний огляд перетинів життєвих доріг письменників виявив суттєві розбіжності їхніх характерів, літературних та світоглядних уявлень. Водночас використання сильних ознак творчих особистостей, взаємоповага та переконаність у необхідності злагодженої роботи забезпечили низку прикладів результативної співпраці Б. Грінченка та М. Коцюбинського в різних ділянках мистецького та громадсько-культурного життя.

${ }^{29}$ О. Пах ль о в с ька, Українсько-італійські літературні зв'язки XIV-XX століть, Київ 1990; Капрійські сюжети: „Італійська” проза Михайла Коиюбинського та Володимира Винниченка, Київ 2003; О. Б а л а б ко, Синьйор Ніколо й синьйор Мікеле: Рим Гоголя й Капрі Кочююбнського: Есеї, Київ 2006.

${ }^{30}$ Н. К К б а льчи ч, Останні часи Б. Д. Грінченка, [в:] Над могилою Бориса Грінченка: Автобіографія, похорон, спомини, статті, Київ 1910, с. 37-44; М. Гр ін че н ко, В Оспедалетті, [в:] Там само, с. 95-104. 